\title{
Generation and cycloaddition of semi-stabilized 2-azaallyllithiums via electrocyclic ring-opening or cycloreversion reactions
}

\author{
William H. Pearson,* Michael A. Walters, Michael K. Rosen, and William G. Harter \\ Department of Chemistry, University of Michigan, Ann Arbor, Michigan, 48109-1055, USA \\ E-mail: wpearson@umich.edu
}

Dedicated to Professor Albert Padwa on his $65^{\text {th }}$ birthday

(received 23 May 02; accepted 12 Aug 02; published on the web 20 Aug 02)

\begin{abstract}
Semi-stabilized 2-azaallyl anions, i.e., those bearing aryl groups, have been generated by either the electrocyclic ring-opening of $N$-lithioaziridines or the 1,3 -anionic cycloreversion of $N$-lithioimidazolidines.
\end{abstract}

Keywords: Aziridine, imidazolidine, cycloreversion, electrocyclic ring-opening, 2-azaallyl anion, 2-azaallyllithium

\section{Introduction}

The $[\pi 4 \mathrm{~s}+\pi 2 \mathrm{~s}]$ cycloadditions of 2-azaallyl anions, particularly 2-azaallyllithiums $\mathbf{1}$ with alkenes $(\mathbf{1} \rightarrow \mathbf{6} \rightarrow 7$, Scheme 1) is a method of growing importance for the synthesis of pyrrolidines. Kauffmann discovered that semi-stabilized ${ }^{1}$ anions bearing two or more aryl rings could be generated by the deprotonation of imines, 2 , with bases such as $\operatorname{LiN}^{i} \mathrm{Pr}_{2} .{ }^{2} \mathrm{We}$ have reported that the deprotonation method could be extended to generate semi-stabilized 2-azaallyllithiums bearing only one aryl group when their cycloadditions were intramolecular. ${ }^{3}$ While nonstabilized ${ }^{1} 2$-azaallyllithiums (i.e., those bearing only alkyl or hydrogen) are not available by the deprotonation technique, we found that tin-lithium exchange on (2-azaallyl)stannanes, 3, was useful for the generation of such anions for both inter- and intramolecular cycloadditions. ${ }^{4,5}$ Despite these successes, we continue to explore other routes to 2-azaallyl anions, since deprotonation is limited to semi-stabilized- (or stabilized-) anion formation and tin-lithium exchange is subject to the usual undesirable attributes of tetraalkyltin chemistry. Herein we report studies on two alternative approaches to 2-azaallyllithium formation, namely the electrocyclic ring-opening of $N$-lithioaziridines, 4, and the 1,3-anionic cycloreversion of $N$ lithioimidazolidines, $\mathbf{5}^{6}$ 
<smiles>[R]C([R])=NC([R])[R]</smiles>

2 deprotonation<smiles>[R]C([R])=NC([R])([R])[Sb]</smiles>

3 Sn-Li exchange<smiles>[R]C1([R])N([Al])C1([R])[R]</smiles>

4<smiles>[R5]C1N([R])C([R])([R])N([Tl])C1([R])[R]</smiles>

5<smiles>[R7]N=C[R]([R])[H]</smiles><smiles>CC=CCCCCC[AsH2+]</smiles><smiles>[R]C1([R])CCC([R])([R])N1[Tl]</smiles>
6 i

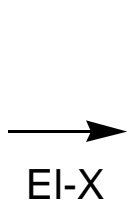

El-X<smiles>[R]C1([R])CCC([R])([R])N1Cl</smiles>

7

Scheme 1. Strategies for the generation of 2-azaallyllithiums (1).

\section{Results and Discussion}

\section{Electrocyclic ring-opening of $\boldsymbol{N}$-lithioaziridines}

Kauffmann reported the conrotatory electrocyclic ring-opening of $c i s$ - and trans- $N$-lithio-2,3diphenylaziridine to 1,3-diphenylazaallyllithium and its use in cycloadditions. ${ }^{2,8}$ However, he reported that the ring opening of $N$-lithio-2-phenylaziridine "proceeds slowly even at $65{ }^{\circ} \mathrm{C}$ ". 7 Successful ring-opening and trapping of this or less activated systems have not been reported. Given that we had successfully used mono-aryl-substituted 2-azaallyllithiums in intramolecular cycloadditions, ${ }^{3}$ we have now explored the use of intramolecularity to probe the scope of the $N$ lithioaziridine approach. 
The aziridine $\mathbf{1 3}$ was synthesized as shown in Scheme 2. Sulfide $\mathbf{9},{ }^{9}$ which was prepared from $\mathbf{8}$, was oxidized to the sulfilimine $\mathbf{1 0} .^{10}$ The sodium salt of $\mathbf{1 0}$ was condensed with benzaldehyde to give the oxirane $\mathbf{1 1}$ as a 9:1 mixture of trans- and cis- isomers. ${ }^{11}$ Nucleophilic ring-opening of $\mathbf{1 1}$ with sodium azide gave 12. At room temperature, only the trans-epoxide reacted, producing 65\% of one diastereomer of $\mathbf{1 2}$ and leaving $20 \%$ of $\mathbf{1 1}$ enriched in the cis isomer. If the reaction was carried out at $70{ }^{\circ} \mathrm{C}$, both isomers of 11 reacted, producing an undesired mixture of diastereomers of 12. A Blum reaction ${ }^{12}$ on $\mathbf{1 2}$ gave the desired aziridine $\mathbf{1 3}$ as the transdiastereomer only.<smiles>C=CCCCCBr</smiles>

8

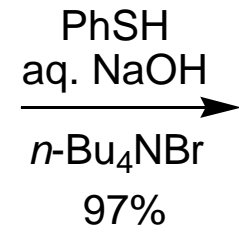<smiles>C=CCCCC1OC1c1ccccc1</smiles>

11 9:1 cis:trans<smiles>C=CCCCC[SeH]</smiles>

9<smiles>C=CCCC[C@H](O)C([N])c1ccccc1</smiles>

12<smiles>[C-]=[N+]=S(CCCCC=C)c1ccccc1</smiles>

1) $\mathrm{NaH}, \mathrm{THF}$

2) $\mathrm{PhCHO}$ 36\%

10

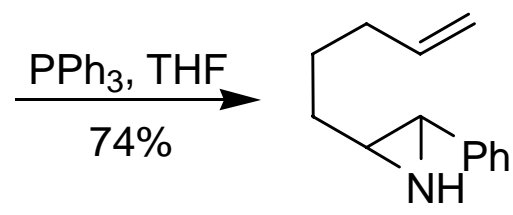

13

Scheme 2. Synthesis of the aziridine 13.

Deprotonation of $\mathbf{1 3}$ with $n$-BuLi failed to afford useful quantities of ring-opened products at ambient temperature in a variety of solvents. However, heating a solution of the lithium salt 15 at $110^{\circ} \mathrm{C}$ in benzene produced the pyrroline 14 in $81 \%$ yield (Scheme 3 ). A solid, presumed to be lithium hydride, was deposited on the walls of the reaction vessel and gave gas evolution upon quenching with water. A likely pathway is a thermally allowed conrotatory ring-opening of 15 to the 2-azaallyllithium 16, which undergoes a $[\pi 4 s+\pi 2 s]$ cycloaddition yielding the $N$ lithiopyrrolidine 17. At this temperature, lithium hydride elimination is apparently facile, a phenomenon that has been observed with lithiated benzylic amines in other systems. ${ }^{13}$ 


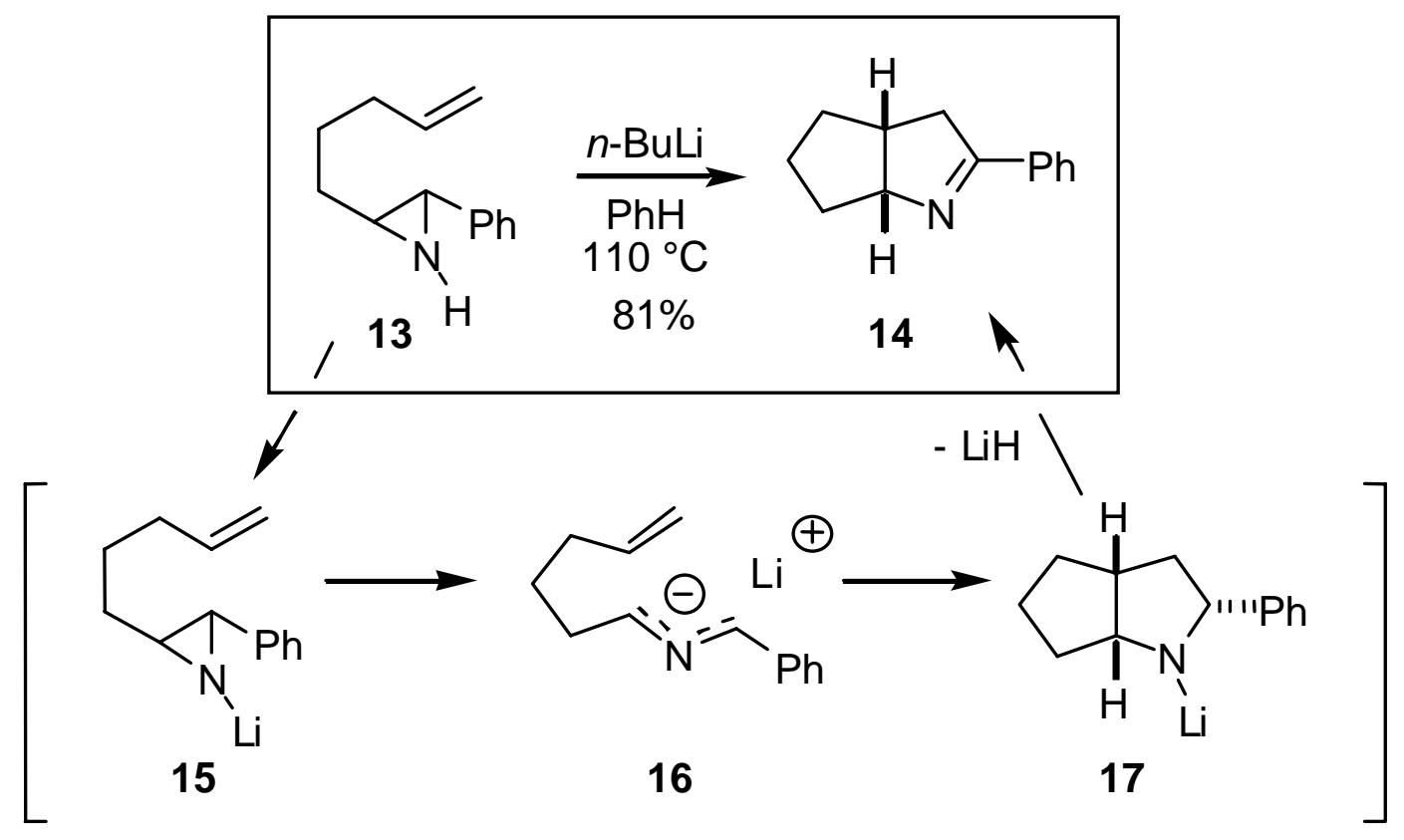

Scheme 3. Electrocyclic ring-opening of $\mathbf{1 5}$ and cycloaddition of $\mathbf{1 6 .}$

Conducting the reaction at lower temperatures $\left(\mathrm{ca} .90^{\circ} \mathrm{C}\right)$ led to low conversions, but traces of the pyrrolidine 18 were observed. Further evidence for the intermediacy of $\mathbf{1 7}$ was obtained by subjection of authentic $18{ }^{3}$ to $n$-BuLi at $110{ }^{\circ} \mathrm{C}$ in benzene (eq. 1), where clean conversion into 14 was observed, with formation of lithium hydride again in evidence.

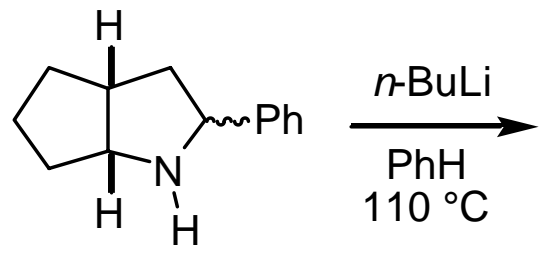

18

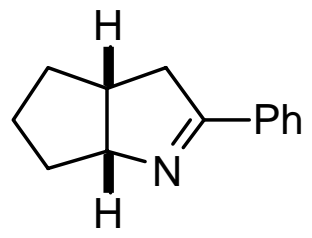

14

Deprotonation of $\mathbf{1 3}$ with $\mathrm{KH}$ in THF in the presence of 18-crown-6 at reflux led to rapid ring-opening but no evidence of cycloaddition.

In an attempt to extend this chemistry to the generation of non-stabilized 2-azaallyl anions, the aziridine $19{ }^{14}$ was prepared and deprotonated with a variety of bases (eq. 2). No cycloadduct 21 (or the pyrroline) was observed. The material identified, other than starting material, was the isomerized alkene 20, formed in low yield when $\mathrm{KH} / 18$-crown-6 was used. 
<smiles>C=CCCCC1NC1C</smiles>

19

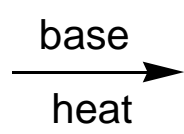

20

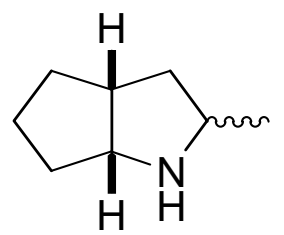

21

In summary, while the aziridine route to 2-azaallyl anions can be extended to include semistabilized anions bearing one phenyl group, it cannot be used to make non-stabilized anions. Further, the conditions required to promote ring-opening of the mono-phenyl $N$-lithioaziridines is significantly higher than that required to open diphenyl $N$-lithioaziridines $\left(110{ }^{\circ} \mathrm{C}\right.$ in benzene $v s$. $66{ }^{\circ} \mathrm{C}$ in THF). At this higher temperature, lithium hydride elimination from the initially formed $N$-lithiopyrrolidine is observed.

\section{1,3-Anionic cycloreversion of $N$-lithioimidazolidines}

As described in the Introduction, our early work on 2-azaallyl anion chemistry showed that semistabilized 2-azaallyllithiums bearing a single phenyl group could be made by deprotonation, as illustrated by the first intramolecular cycloaddition of such an anion (Scheme 4). ${ }^{3}$ During the course of the present work, we uncovered a new route to 2-azaallyl anions, namely the 1,3anionic cycloreversion of $N$-lithioimidazolidines (eq. 3). We now report the discovery of this method, and studies of its scope.

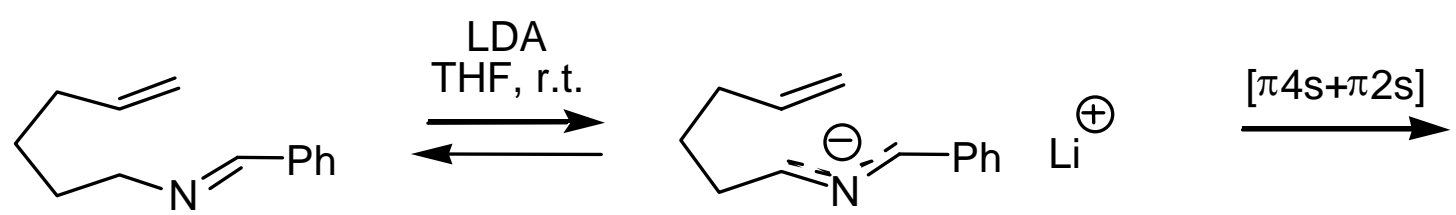

22

16

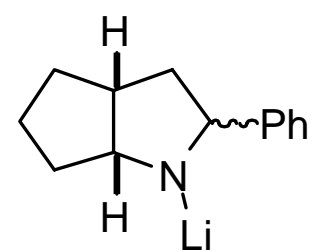

17
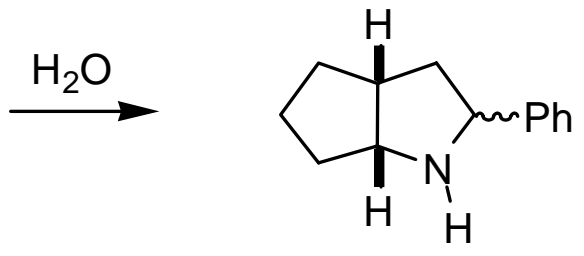

18a: $-\mathrm{Ph}$

18b: "'"'Ph

Scheme 4. Deprotonation route to the 2-azaallyllithium 16 and its cycloaddition. 
<smiles>[R]C=N[R]</smiles>

When the reaction in Scheme 4 was followed by GC, the expected first-order kinetics were not observed; in fact, evidence for an intermediate was obtained. Performing the deprotonation in THF-d ${ }^{8}$ allowed observation of the rapid buildup of two new compounds by ${ }^{1} \mathrm{H}-\mathrm{NMR}$, which were assigned as the lithio-imidazolidines 23 and 24 (Scheme 5). These were slowly converted to the bicyclic $N$-lithiopyrrolidine 17 after several hours at room temperature, producing the pyrrolidines 18 after workup. Apparently, the initial deprotonation of 22 is slow enough to allow intermolecular cycloaddition with the imine portion of a second molecule of 22. Cycloadditions of 2-azaallyl anions with imines to give imidazolidines have been observed by others. ${ }^{2,15,16}$ The reverse process, namely the anionic cycloreversion of the lithioimidazolidines to the 2-azaallyl anion, is now implicated by the results shown in Scheme 5. This process has not been previously observed, although similar anionic cycloreversions are known. ${ }^{2,1719}$

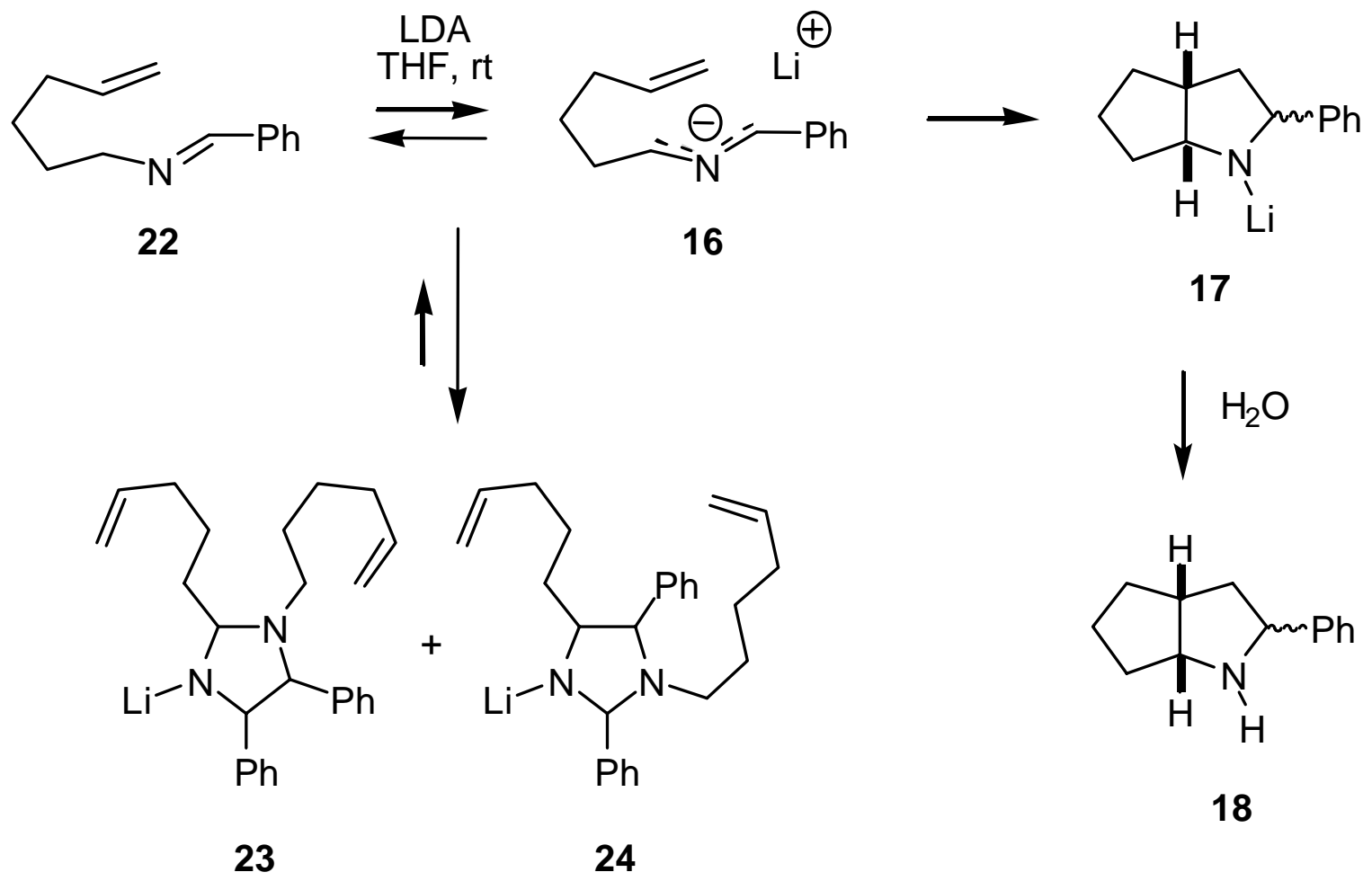

Scheme 5. Intermediacy of imidazolidines in the deprotonation route. 
In a separate experiment (Scheme 6), workup of the deprotonation reaction at partial conversion allowed the isolation of the imidazolidines $\mathbf{2 5}$ and $\mathbf{2 6}$ of undefined stereochemistry. Re-subjection of these imidazolidines to the same reaction conditions (LDA, THF, room temperature) also gave 18. Hence, for the first time, it has been demonstrated that $N$ lithioimidazolidines are subject to anionic cycloreversion to 2-azaallyl anions. This may allow a new route to 2-azaallyl anions that does not rely on imine deprotonation, thereby perhaps obviating the need for a non-enolizable imine. For example, imidazolidines might be synthesized from carbonyl compounds and vicinal diamines, then subjected to base to produce $N$ lithioimidazolidines and thus 2-azaallyl anions (vide infra).

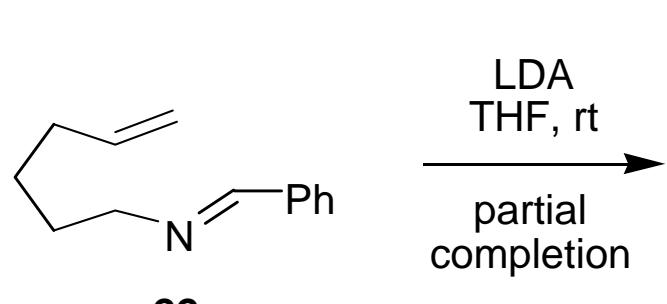

22

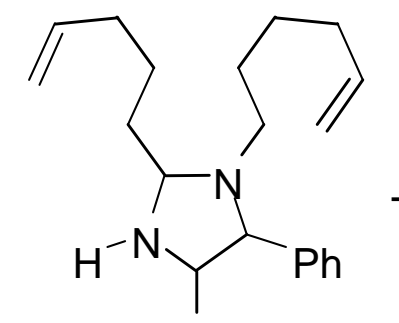

$\mathrm{Ph}$

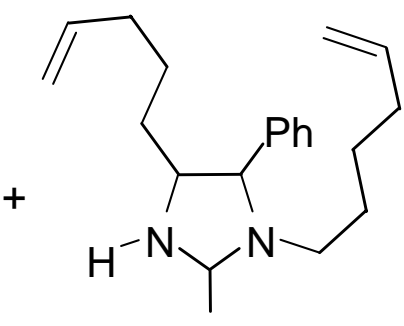

$\mathrm{Ph}$

26

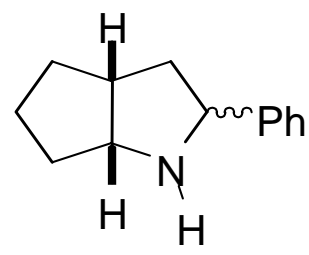

1) LDA, rt

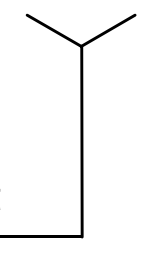

2) $\mathrm{H}_{2} \mathrm{O}$

Scheme 6. Imidazolidine isolation and use.

Deprotonation of the imine 27, which cannot lead to cycloaddition owing to the absence of an alkene, resulted in the formation of the imidazolidines 28 and 29 (Scheme 7). Interestingly, the regioselectivity of the dimerization was found to depend on the solvent, providing complementary results. The stereochemistry of these imidazolidines is unknown, although the phenyl groups on $\mathbf{2 9}$ were later found to be trans by synthesizing this compound via an unambiguous route. 


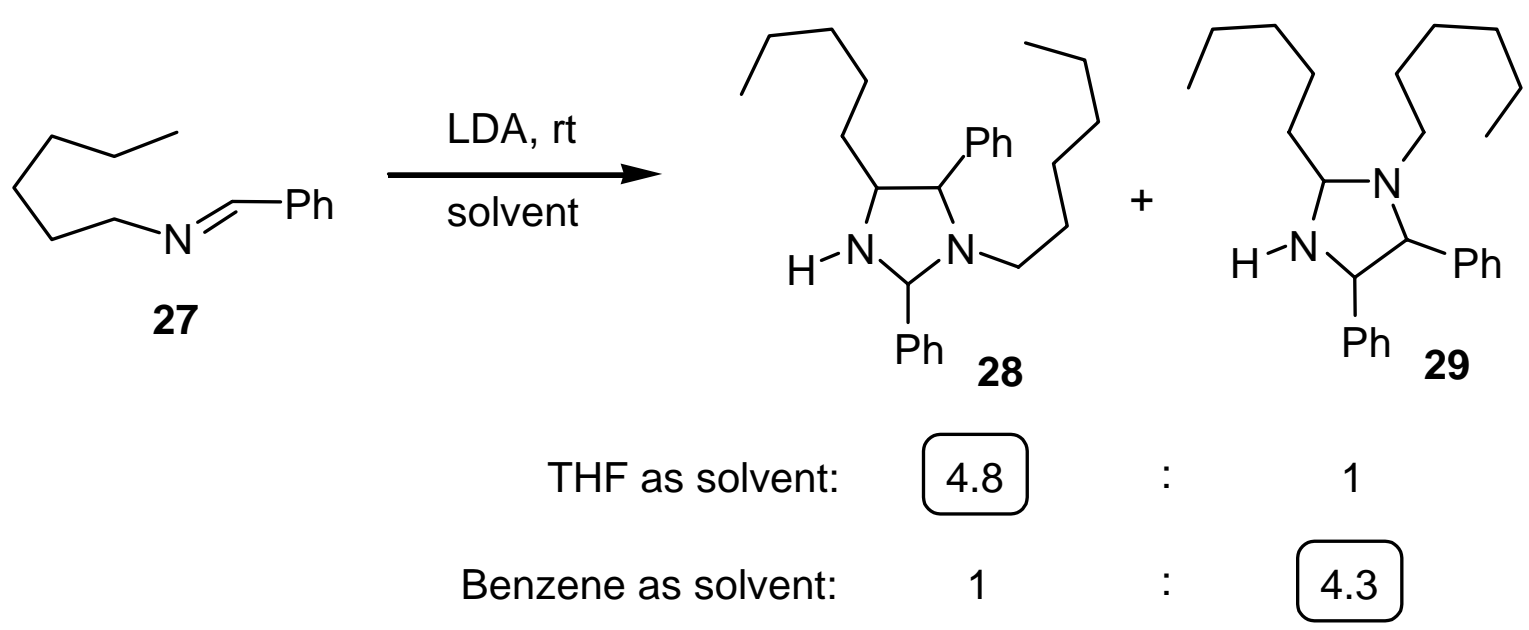

Scheme 7. Deliberate synthesis of imidazolidines from a 2-azaallyllithium.

The imidazolidines $\mathbf{2 8}$ and $\mathbf{2 9}$ were found to be good precursors of 2-azaallyl anions (Scheme 8). Addition of LDA to a mixture of 28, 29, and trans-stilbene afforded the pyrrolidine $\mathbf{3 0}$ as a mixture of three stereoisomers. The imidazolidines used were those formed in the THF reaction in Scheme 7. Thus, definitive evidence for the generation of a 2-azaallyl anion (namely, 31) from imidazolidines was gathered.<smiles>CCCCCCN1C(C)NC(CCCCC)C1c1ccccc1</smiles>

$\mathrm{Ph}$<smiles>CCCCCCN1C(CCCCC)NC(Pc2ccccc2)C1c1ccccc1</smiles>

29 (minor)
$\mathrm{Ph}$

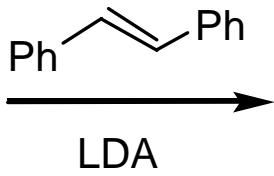

28 (major)

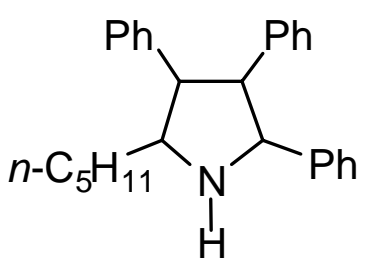

$30(62 \%)$

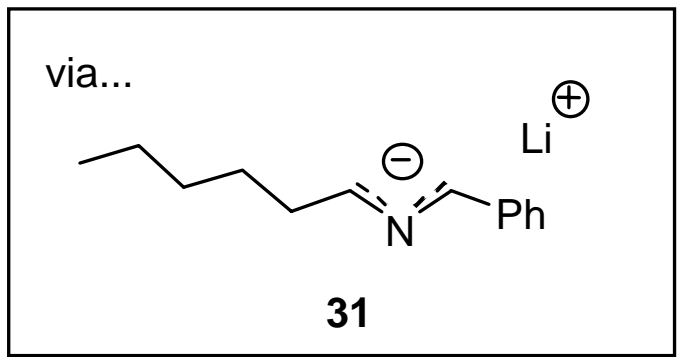

Scheme 8. Cycloreversion of imidazolidines and intermolecular cycloaddition of the resultant 2azaallyllithium. 
Since imidazolidines may be prepared from diamines and aldehydes, we sought to explore this method as a route to 2-azaallyl anions. Initially, we prepared the diamines $\mathbf{3 2}$ and $\mathbf{3} 3$ from the imidazolidines 28 and 29 (Scheme 9). The imidazolidines used in this case were derived from the benzene experiment in Scheme 7. The diamine $\mathbf{3 3}$ was formed as the major product upon acidic hydrolysis. Condensation of 33 with 5-hexenal in a Dean-Stark apparatus afforded the imidazolidine 34, which was treated with LDA. Cycloreversion to the 2-azaallyl anion and $N$ benzylidinehexylamine occurred, leading to the bicyclic pyrrolidines 18. Unfortunately, the $N$ benzylidinehexylamine by-product dimerized to the imidazolidines $\mathbf{2 8}$ and 29, making the workup and isolation of $\mathbf{1 8}$ difficult. Nonetheless, this experiment showed that diamines may be used as starting materials for 2-azaallyl anion chemistry.<smiles>CCCCCCC1N(CCCCCC)C(Pc2ccccc2)C(c2ccccc2)N1CCCCCC</smiles>

28 (minor) 29 (major)

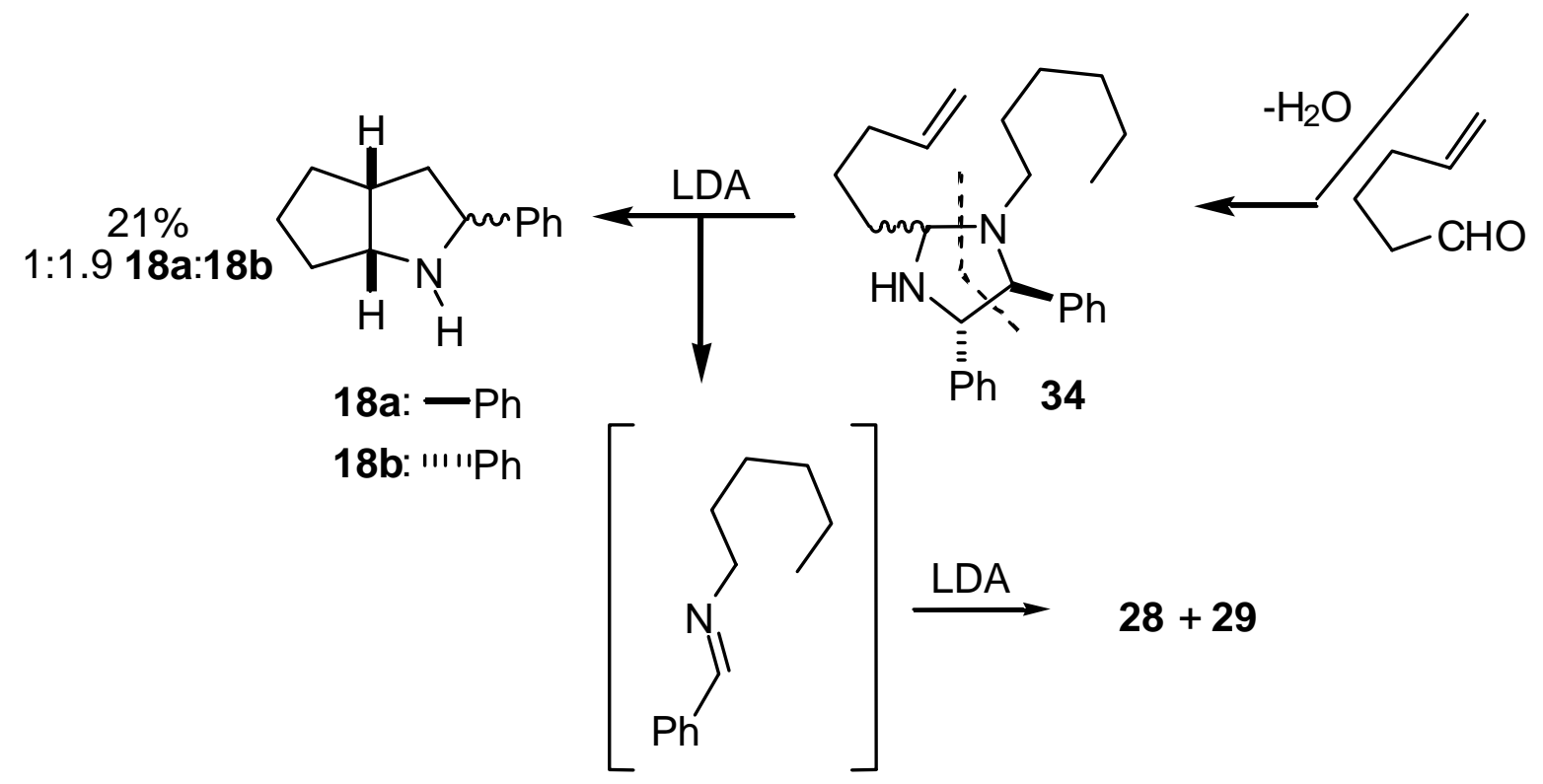

Scheme 9. Hydrolysis of imidazolidines to diamines and their use in the preparation of new imidazolidines.

To avoid the dimerization of the imine by-product of the imidazolidine cycloreversion, we synthesized the $N$-isopropyl diamine 37 from $\left(d, l\right.$-)-stilbenediamine $35^{20}$ by a reductive amination approach (Scheme 10). We hoped that imidazolidines derived from 37 would form $N$ - 
benzylidineisopropylamine as a by-product, which might not dimerize, owing to steric considerations. Scheme 10 shows the successful conversion of $\mathbf{3 7}$ to the imidazolidines $\mathbf{3 8}$ and 39. The relative configuration at $\mathrm{C}-2$ of these compounds is assumed to be as shown, based on molecular modeling (MM2), with the assumption that the most stable diastereomer would be formed under the condensation conditions.

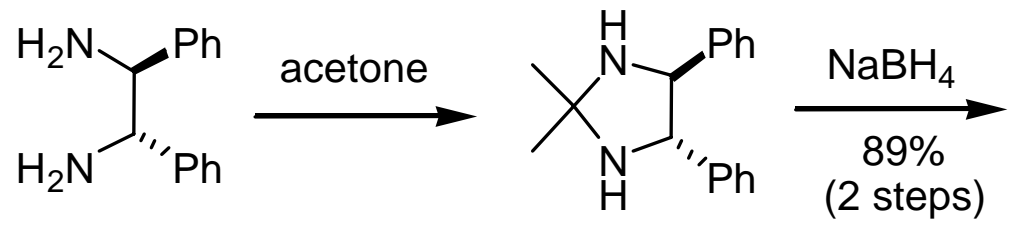

35

36

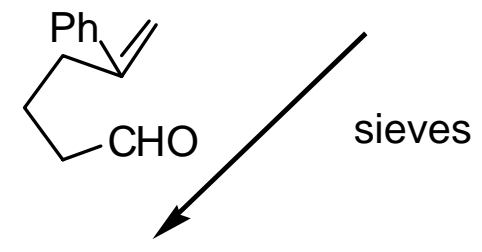

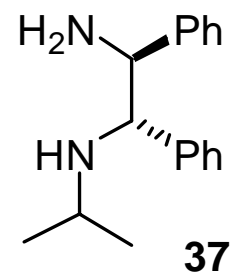

37

$39(86 \%)$

Scheme 10. Synthesis of "designed" imidazolidines.

With the imidazolidines 38 and 39 in hand, we subjected these compounds to deprotonation with $n$-butyllithium (Scheme 11). Smooth cycloreversion of the $N$-lithioimidazolidines occurred, leading to the cycloadducts $\mathbf{1 8}$ and $\mathbf{4 0}$. No by-products were observed from the dimerization of $\mathrm{N}$-benzylidineisopropylamine, which was observed in nearly quantitative amounts by GC. 


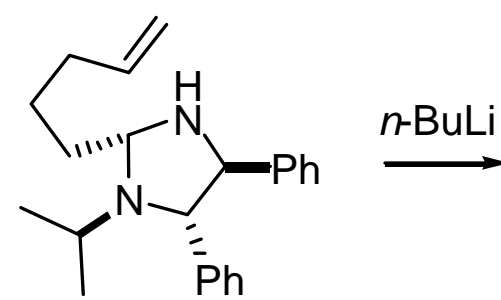

38

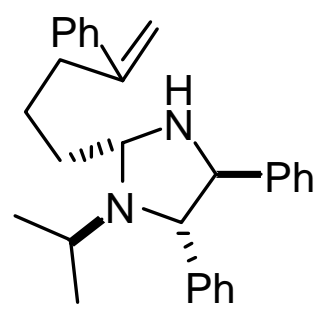

39

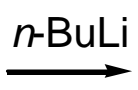

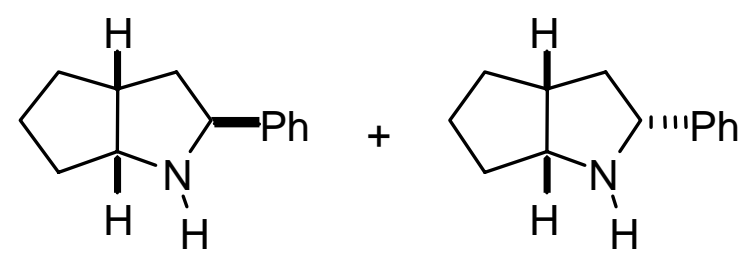

$18 \mathrm{a}$

$49 \%(1: 10)$

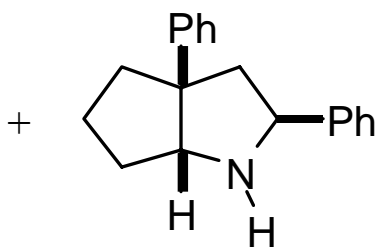

$40 \mathrm{~b}$

$40 a$

$53 \%(1: 11)$

Scheme 11. Cycloreversion of "designed" imidazolidines.

Scheme 12 summarizes the stereochemical outcome of the imidazolidine method and the deprotonation method for 2-azaallyl anion synthesis. Note that in each case, the two routes give opposite stereochemical outcomes. The pyrrolidines 18b and 40a are the likely result of cycloaddition through the "W"-geometry of the 2-azaallyl anion, while pyrrolidines 18a and 40b must arise through a "sickle"-geometry. It is certainly believable that the imidazolidine method and the deprotonation method may give different anion geometries. However, there are several curious aspects to this hypothesis. First, as determined above, the deprotonation of 22 goes through imidazolidines! Why, then, would these imidazolidines and $\mathbf{3 8}$ give different results? Possible explanations include, (1), the idea that imidazolidines 25 and 26 (Scheme 6) each produce different 2-azaallyl anion geometries, and, (2), that the stereochemistry of $\mathbf{3 8}$ (particularly at $\mathrm{C}-2$ ) is different from the stereochemistry of imidazolidine 25 (Scheme 6), perhaps leading to a different 2-azaallyl anion geometry. This explanation is, however, contradicted by the results shown at the bottom of Scheme 12. Note that 39, an imidazolidine analogous to 38, gives products resulting from the sickle- rather than $\mathrm{W}$-anion geometry. How can the simple change of placing a phenyl group on the anionophile cause such a reversal? Also surprising is the fact that the deprotonation of $\mathbf{4 1}$ gives results opposite to those observed in the deprotonation of 22. However, no evidence for imidazolidine intermediates was obtained in the deprotonation of 41, so these two experiments are not entirely comparable. The relative configurations of the bicyclic pyrrolidines shown in Scheme 12 were vouchsafed by differenceNOE ${ }^{1} \mathrm{H}-\mathrm{NMR}$ experiments. 
<smiles>C=CCCC[C@@H]1N[C@@H](c2ccccc2)[C@H](Pc2ccccc2)N1C(C)C</smiles>

38
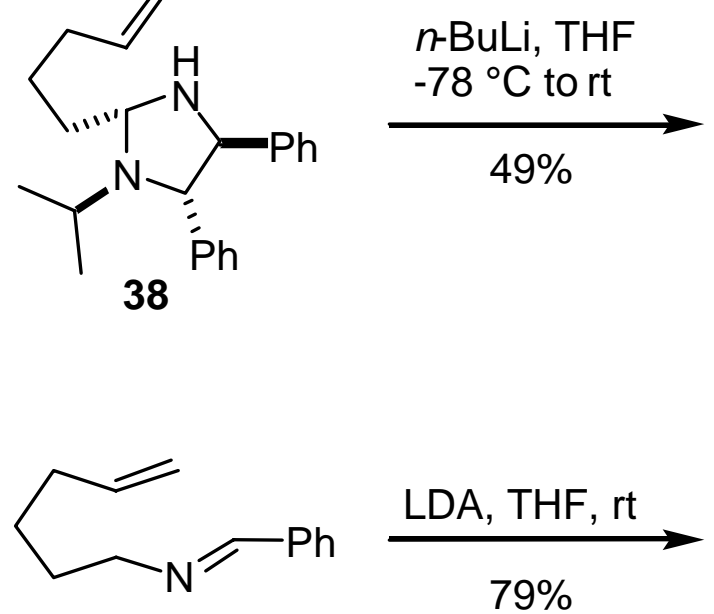<smiles>[PH3+]c1ccccc1</smiles>

$18 b$<smiles>c1ccc([PH2+]C2C[C@@H]3CCC[C@H]3N2)cc1</smiles>

$18 a$

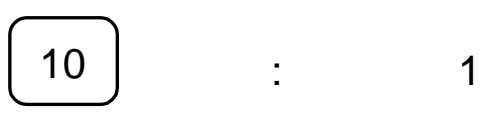

22<smiles>C=CC(C)N1[C@H](c2ccccc2)C(c2ccccc2)[C@H](c2ccccc2)N1C(C)C</smiles>

39

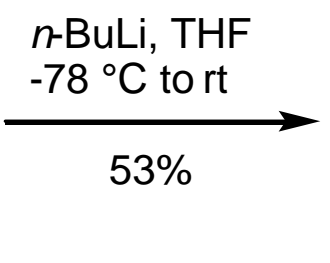

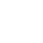
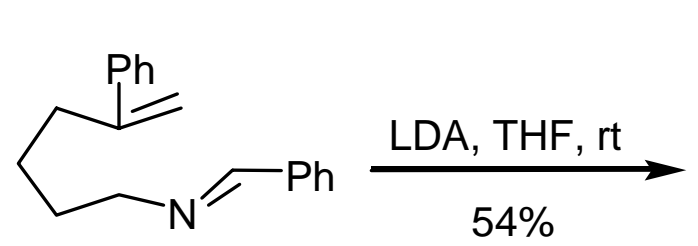<smiles>[PH3+][C@H]1C[C@]2(c3ccccc3)CCC[C@H]2N1</smiles>

$40 a$

1

6<smiles>[PH3+]C1C[PH2+](c2ccccc2)[C@@H]2CCC[C@@H]12</smiles>

$40 b$

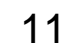

1

41

Scheme 12. Stereochemical comparison of the deprotonation and imidazolidine routes.

Studies meant to explore the scope of the $N$-lithioimidazolidene cycloreversion route were implemented. Scheme 13 shows some imidazolidines that failed to undergo cycloreversion / cycloaddition. The first compound shows that an $N$-aryl substituent inhibits the reaction. The remaining compounds show that, regardless of the $N$-substituent, no cycloreversion is observed where the 2-azaallyl anion would be non-stabilized (i.e., no C-aryl substituent). Our tin-lithium exchange methodology thus remains as the only method available for the generation of such nonstabilized anions. 

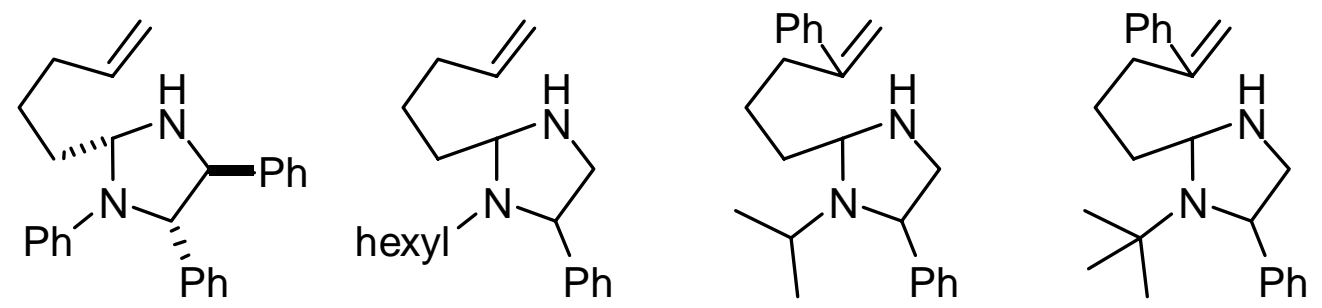

Scheme 13. Imidazolidines that fail to give cycloreversion/cycloaddition products.

\section{Conclusions}

The electrocyclic ring-opening of $N$-lithioaziridines and the 1,3-anionic cycloreversion of $N$ lithioimidazolidines to 2-azaallyl anions have been shown to produce semi-stabilized 2azaallyllithiums bearing a single phenyl group. However, extension of either of these methods to the generation of non-stabilized 2-azaallyl anions fails, leaving tin-lithium exchange as the only viable method for the generation of such anions.

\section{Experimental Section}

5-Hexenyl phenyl sulfide (9). Thiophenol (11.2 g, $102 \mathrm{mmol})$ was added to a solution of sodium hydroxide (5.2 g. $130 \mathrm{mmol})$ dissolved in $100 \mathrm{~mL}$ of water. After $10 \mathrm{~min}$, 6-bromo-1-hexene (8, $16.3 \mathrm{~g}, 100 \mathrm{mmol})$ and tetrabutylammonium bromide (40 mg, $12.5 \mathrm{mmol})$ were added. After refluxing $16.5 \mathrm{~h}$, the mixture was cooled and extracted with ether. The organic phase was washed three times with $4 M$ sodium hydroxide solution and dried over magnesium sulfate. Kugelrohr distillation gave $18.54 \mathrm{~g}$ (97\%) of the known title compound, ${ }^{9}{ }^{1} \mathrm{H}-\mathrm{NMR}\left(60 \mathrm{MHz}, \mathrm{CDCl}_{3}\right): \delta$ $7.3(\mathrm{~m}, 5 \mathrm{H}), 5.7(\mathrm{~m}, 1 \mathrm{H}), 5.0(\mathrm{~m}, 2 \mathrm{H}), 2.9(\mathrm{t}, 2 \mathrm{H}), 2.0(\mathrm{~m}, 3 \mathrm{H}), 1.5(\mathrm{~m}, 4 \mathrm{H})$.

Sulfilimine 10. Glacial acetic acid $(0.5 \mathrm{~g}, 9 \mathrm{mmol})$ was added over ten minutes to a solution of the sulfide 9 (1.04 g, $5.4 \mathrm{mmol})$ and chloramine-T $(1.22 \mathrm{~g}, 5.36 \mathrm{mmol})$ in methanol $(15 \mathrm{~mL})$. After $15 \mathrm{~min}$ at room temperature and $2.5 \mathrm{~h}$ at $50{ }^{\circ} \mathrm{C}$, additional chloramine- $\mathrm{T}(0.11 \mathrm{~g}$, $0.53 \mathrm{mmol}$ ) was added. After $1 \mathrm{~h}$ more at $50{ }^{\circ} \mathrm{C}$, the solution was poured into $80 \mathrm{~mL}$ of $1 \mathrm{M}$ sodium hydroxide, causing a precipitate to form. The solid was collected by filtration and recrystallized (acetone/hexane) to give $1.35 \mathrm{~g} \mathrm{(69 \% )} \mathrm{of} \mathrm{the} \mathrm{title} \mathrm{compound} \mathrm{as} \mathrm{a} \mathrm{flaky} \mathrm{white} \mathrm{solid,}$ m.p. $68-78{ }^{\circ} \mathrm{C}$. In later runs, the product was purified using flash column chromatography $(50 \%$ ethyl acetate in hexane), which gave material of higher purity, m.p. 89-91 ${ }^{\circ} \mathrm{C} .{ }^{1} \mathrm{H}-\mathrm{NMR}(300$ $\left.\mathrm{MHz}_{\mathrm{CDCl}}\right): \delta 7.75(\mathrm{dt}, J=9.2,1.9 \mathrm{~Hz}, 2 \mathrm{H}), 7.68(\mathrm{~m}, 2 \mathrm{H}), 7.5(\mathrm{~m}, 3 \mathrm{H}), 5.22(\mathrm{dd}, J=8.0,0.6$ $\mathrm{Hz}, 2 \mathrm{H}), 5.65(\mathrm{~m}, 1 \mathrm{H}), 4.95(\mathrm{~m}, 2 \mathrm{H}), 3.08(\mathrm{~m}, 1 \mathrm{H}), 2.88(\mathrm{~m}, 1 \mathrm{H}), 2.35(\mathrm{~s}, 3 \mathrm{H}), 1.94(\mathrm{qt}, J=7.0$, $1.2 \mathrm{~Hz}, 2 \mathrm{H}), 1.58$ (m, 2H), 1.40 (m, 2H); IR (KBr pellet) 1305 (s), 1284 (s), 1142 (s), 1088 (s) $\mathrm{cm}^{-1}$; MS (EI), m/z (\%): 220 (8), 219 (13), 218 (87), 185 (11), 154 (13), 109 (100), 69 (15), 65 
(32) 1-(4-Pentenyl)-2-phenyloxirane (11). The sulfilimine 10 (10.48 g, $28.99 \mathrm{mmol})$ in THF $(80 \mathrm{~mL})$ was added to freshly washed sodium hydride $(1.078 \mathrm{~g}, 44.93 \mathrm{mmol})$. After $5.5 \mathrm{~h}$, benzaldehyde ( $3.38 \mathrm{~g}, 31.89 \mathrm{mmol})$ in THF $(25 \mathrm{~mL})$ was added. After $40 \mathrm{~h}$, water was added and the mixture was extracted with light petroleum $(3 \mathrm{x})$. The organic extracts were combined, washed twice with brine, and dried $\left(\mathrm{MgSO}_{4}\right)$. Chromatography (15\% ethyl acetate in hexane) gave $3.02 \mathrm{~g}(36 \%)$ of the title compound as a 9:1 mixture of trans- and cis- isomers. ${ }^{1} \mathrm{H}-\mathrm{NMR}$ $\left(300 \mathrm{MHz}, \mathrm{CDCl}_{3}\right),\left[{ }^{*}\right.$ indicates trans isomer, ${ }^{*}$ indicates cis- isomer] $\delta 7.3(\mathrm{~m}, 5 \mathrm{H}), 5.8^{*}(\mathrm{~m}$, $1 \mathrm{H}), 5.7^{\#}(\mathrm{~m}, 1 \mathrm{H}), 5.0^{*}(\mathrm{~m}, 2 \mathrm{H}), 4.1^{\#}(\mathrm{~d}, J=4.4 \mathrm{~Hz}, 1 \mathrm{H}), 3.6^{*}(\mathrm{~d}, J=2.1 \mathrm{~Hz}, 1 \mathrm{H}), 3.2^{\#}(\mathrm{dt}, J=$ 2.0, 4. $1 \mathrm{~Hz}, 1 \mathrm{H}), 2.95^{*}(\mathrm{dt}, J=5.6,2.1 \mathrm{~Hz}, 1 \mathrm{H}), 2.1^{*}(\mathrm{qt}, J=6.9,1.4 \mathrm{~Hz}, 2 \mathrm{H}), 2.0^{\#}(\mathrm{qt}, J=7.1$, $1.2 \mathrm{~Hz}, 2 \mathrm{H}), 1.6(\mathrm{~m}, 4 \mathrm{H})$; IR (neat) 1640.7 (m) cm $\mathrm{cm}^{-1}$; MS, $m / z(\%) 187$ (18, $\left.\mathrm{M}^{+}\right), 159$ (1), 145 (1), 129 (3), 117 (10), 107 (46), 105 (38), 91 (36), 90 (34), 89 (36), 79 (38), 67 (100).

7-Azido-7-phenyl-1-heptene-6-ol (12). Sodium azide (1.80 g, $27.7 \mathrm{mmol})$ was added to a solution of the oxirane $11(0.516 \mathrm{~g}, 2.74 \mathrm{mmol})$ and triethylamine $(50 \mu \mathrm{L})$ in methanol $(40 \mathrm{~mL})$. After 4 days, water was added and the solution was extracted with ether $(3 \mathrm{x})$. The organic extracts were washed with brine $(3 \mathrm{x})$ and dried $\left(\mathrm{MgSO}_{4}\right)$. Chromatography $(15 \%$ ethyl acetate in hexane) gave $0.0976 \mathrm{~g}$ (19\%) of the oxirane 11 (2.2: 1 trans-: cis-) and $0.334 \mathrm{~g}(53 \%)$ of the title compound as a single diastereomer. ${ }^{1} \mathrm{H}-\mathrm{NMR}\left(300 \mathrm{MHz}, \mathrm{CDCl}_{3}\right) \delta 7.4(\mathrm{~m}, 5 \mathrm{H}), 6.75(\mathrm{~m}$, $1 \mathrm{H}), 4.98(\mathrm{~m}, 2 \mathrm{H}), 4.48$ (d, $J=5.8 \mathrm{~Hz}, 1 \mathrm{H}), 4.8$ (broad S, 1H), 2.05 (m, 2H), 1.5 (m); IR (neat) 3435 (br), 2103 (s), 1641 (m) cm cm $^{-1}$ MS m/z (\%) 203 (29, $\mathrm{M}^{+}-\mathrm{N}_{2}$ ), 174 (6), 160 (15), 146 (24), 144 (19), 133 (23), 132 (36), 117 (7), 106 (100), 91 (28), 77 (35).

trans-2-(4-Pentenyl)-3-phenylaziridine (13). Triphenylphosphine (0.856 g, $3.25 \mathrm{mmol})$ was added to a solution of $12(0.742 \mathrm{~g}, 3.12 \mathrm{mmol})$ THF $(15 \mathrm{~mL})$. After heating at reflux for $5 \mathrm{~h}$, the mixture was cooled and concentrated. The residue was purified by column chromatography (24 $\%$ ethyl acetate in hexane) to give $0.432 \mathrm{~g}(74 \%)$ of the title compound as a single diastereomer. ${ }^{1} \mathrm{H}-\mathrm{NMR}\left(300 \mathrm{MHz}, \mathrm{CDCl}_{3}\right) \delta 7.26(\mathrm{~m} .5 \mathrm{H}), 5.81(\mathrm{~m}, 1 \mathrm{H}), 4.99(\mathrm{~m}, 2 \mathrm{H}), 2.69$ (d, $J=2.4 \mathrm{~Hz}$, $1 \mathrm{H}), 2.11(\mathrm{~m}, 3 \mathrm{H}), 1.60(\mathrm{~m}, 4 \mathrm{H}), 0.62(\mathrm{~s}, 1 \mathrm{H}) ;{ }^{13} \mathrm{C}-\mathrm{NMR}\left(300 \mathrm{MHz}, \mathrm{CDCl}_{3}\right) \delta 140.4,138.3$, 128.3, 127.6I, $186,126.8,125.4,114.7,41.7,39.4,33.9,33.3,26.7$; IR (neat) 3292 (m), 3238 (m), 1640 (m) cm $\mathrm{cm}^{-1}$ MS m/z (\%) 188 (4), 187 (6) P (13), 158 (20), 144 (25), 132 (42), 130 (9), 117 (12), 110 (14), 106 (16), 105 (69), 104 (39), 91 (39), 77 (40), 39 (100).

Pyrroline 14. Aziridine $13(39.5 \mathrm{mg}, 0.211 \mathrm{mmol})$ was dissolved in benzene $(2.2 \mathrm{~mL})$ and transferred into a pressure tube with a screw-in Teflon seal. The solution was cooled to its freezing point and $n$-butyl lithium $(144 \mu \mathrm{L} 2.5 \mathrm{M}$ in hexane, $0.360 \mathrm{mmol})$ was added. The tube was sealed and maintained at $110^{\circ} \mathrm{C}$ for 44 hours, during which time the liquid became dark brown and a white precipitate formed. The reaction was quenched by the addition of wet ether, which caused gas evolution with concomitant disappearance of the solid. Water was added and the mixture was extracted with ether $(3 \mathrm{x})$. The extracts were combined, washed three times with brine, and dried $\left(\mathrm{MgSO}_{4}\right)$. Chromatography (15\% ethyl acetate in hexane) gave $31.5 \mathrm{mg}(81 \%)$ of the title compound, ${ }^{1} \mathrm{H}-\mathrm{NMR}\left(300 \mathrm{MHz}, \mathrm{CDCl}_{3}\right) \delta 7.82(\mathrm{~m}, 2 \mathrm{H}), 7.41(\mathrm{~m}, 3 \mathrm{H}), 4.79(\mathrm{~m}, 1$ H), 3.22 (ddd, $J=17.6,9.8,1.5 \mathrm{~Hz}, 1 \mathrm{H}), 2.78(\mathrm{~m}, 2 \mathrm{H}), 1.84(\mathrm{~m}, 3 \mathrm{H}), 1.56(\mathrm{~m}, 1 \mathrm{H}), 1.42(\mathrm{~m}, 2$ $\mathrm{H})$; IR (neat) 1617 (s), 1576 (s) cm $\mathrm{cm}^{-1}$ MS, m/z (\%) 186 (14, $\mathrm{M}^{+}$), 185 (77), 157 (12), 156 (58), 
144 (5), 143 (10), 130 (9), 129 (5), 128 (6), 115 (10), 104 (94), 82 (59), 77 (19), 67 (100), 54 (32); HRMS shows $\mathrm{C}_{13} \mathrm{H}_{15} \mathrm{~N}$.

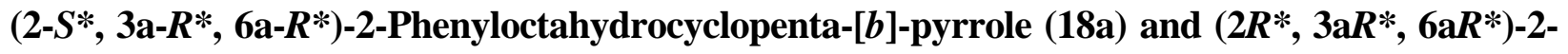
phenyloctahydrocyclopenta-[b]-pyrrole (18b). Procedure 1. Imine deprotonation. A solution of $N$-benzylidene-5-hexen-1-amine (22) (357 mg, $1.90 \mathrm{mmol}$ ) in THF (4 mL) was added in a dropwise fashion to a cold $\left(-78^{\circ} \mathrm{C}\right)$ solution of lithium diisopropylamine (LDA, $3.42 \mathrm{mmol}$, from $n$-butyllithium and diisopropylamine) in THF $(34 \mathrm{~mL})$. After warming to room temperature for $18 \mathrm{~h}$, the black solution was diluted with water and extracted twice with ether. The organic phases were combined, washed with saturated aqueous sodium chloride, dried $\left(\mathrm{MgSO}_{4}\right)$, and concentrated to give an orange residue. Flash chromatography $\left(2-10 \% \mathrm{MeOH} \mathrm{CHCl}_{3}\right.$ gradient elution) gave $282 \mathrm{mg}$ (79\%) of a 4.1:1 mixture of 18a and 18b. Characterization on a mixture of 18a and 18b: IR (neat) 3336 (w), 2948 (s), 2859 (m), 1948 (w), 1881 (w), 1808 (w), 1493 (w), $1448(\mathrm{~m}), 699(\mathrm{~s}) \mathrm{cm}^{-1}$; Anal. Calcd. for $\mathrm{C}_{13} \mathrm{H}_{17} \mathrm{~N}$ : C, 83.36; H, 9.15; N, 7.48. Found: C, 83.32; $\mathrm{H}, 9.26$; $\mathrm{N}, 7.28$. Characterization of pure major isomer 18 26.5, 63.5, 61.3, 42.8, 42.5, 36.2, 33.7, 15.9. MS (EI, m/z) 187 (50), 186 (54), 158 (90), 144 (89), 132 (48), 110 (100), 104 (78), 91 (50), 77 (39). Characterization of pure minor isomer 18b: ${ }^{1} \mathrm{H}-\mathrm{NMR}\left(360 \mathrm{MHz}, \mathrm{CDCl}_{3}\right) \delta 3.99$ $(\mathrm{dd}, 1 \mathrm{H}, J=5.3,10.9 \mathrm{~Hz}), 3.74(\mathrm{t}, 1 \mathrm{H}, J=7.7 \mathrm{~Hz}), 2.6(\mathrm{~m}, 1 \mathrm{H}), 2.3(\mathrm{ddd}, 1 \mathrm{H}, J=5.5,9,12 \mathrm{~Hz})$, $1.27(\mathrm{~m}, 1 \mathrm{H}) ;{ }^{13} \mathrm{C}-\mathrm{NMR}\left(75 \mathrm{MHz}, \mathrm{CDCl}_{3}\right) \delta 128.7,127.0,126.7,63.8,63.4,43.1,43.9,34.6$, 33.1, 23.8. MS (EI, m/z) 187 (80), 186 (83), 158 (100), 144 (66), 132 (39), 110 (53), 105 (31), 104 (51), 91 (34), 77 (31), 67 (29), 41 (49), 39 (36); HRMS: calcd., 187.1361; found, 187.1356.

Procedure 2: cycloreversion of imidazolidine 34. A solution of $0.185 \mathrm{~g}$ ( $0.494 \mathrm{mmol})$ of 34 (see below) in $5.0 \mathrm{~mL}$ of dry THF was cooled to $-70{ }^{\circ} \mathrm{C}$ and treated with $0.65 \mathrm{~mL}$ (1.0 mmol) of a 1.6 M solution of LDA in cyclohexane. The solution became orange-colored and was allowed to warm slowly to room temperature. After $72 \mathrm{~h}$, water was added, and the mixture was extracted with ether. The organic layer was washed with brine, dried $\left(\mathrm{MgSO}_{4}\right)$, and concentrated to give $0.142 \mathrm{~g}$ (77\% crude yield) of a deep-red liquid. ${ }^{1} \mathrm{H}-\mathrm{NMR}$ showed this to be a mixture of 18 contaminated with imidazolidines $\mathbf{2 8}$ and $\mathbf{2 9}$ and vinylic-hydrogen-containing side-products. There was no starting material. The bicyclic pyrrolidines could be separated by gradient chromatography (5-100\% ethyl acetate/ hexane) on silica gel, producing $18.8 \mathrm{mg}$ (21\% yield) of a 1:1.87 mixture of $\mathbf{1 8 a}$ and $\mathbf{1 8 b}$.

Procedure 3: imidazolidine cycloreversion. $n$-Butyllithium $(0.280 \mathrm{~mL}$ of a $1.56 \mathrm{M}$ solution in hexane, $0.437 \mathrm{mmol})$ was added in a dropwise fashion to a cold $\left(-78{ }^{\circ} \mathrm{C}\right)$ solution of the imidazolidine 38 (116 mg, $0.347 \mathrm{mmol}$, see below for preparation) in THF (35 mL). After 10 min, the solution was warmed to room temperature for $5 \mathrm{~h}$. The dark solution was diluted with water and extracted with ether. The organic layer was washed with brine, dried $\left(\mathrm{MgSO}_{4}\right)$, and concentrated. Chromatography as above gave $31.7 \mathrm{mg}(49 \%)$ of a 1:10 mixture of 18a and 18b. 
$\left(2 R^{*}, 3 a S^{*}, 6 a R^{*}\right)-2,3 a-D i p h e n y l o c t a h y d r o c y c l o p e n t a-[b]-p y r r o l e ~(40 a)$ and (2S*, 3aS*, 6aR*)-2,3a-Diphenyloctahydrocyclopenta-[b]-pyrrole (40b).

Procedure 1: imine deprotonation. A solution of $N$-benzylidene-5-phenyl-5-hexen-1-amine (41) $(329 \mathrm{mg}, 1.25 \mathrm{mmol})$ in THF $(4 \mathrm{~mL})$ was added in a dropwise fashion to a cold $\left(-78{ }^{\circ} \mathrm{C}\right)$ solution of lithium diisopropylamine (LDA, $2.1 \mathrm{mmol}$, from $n$-butyllithium and diisopropylamine) in THF $(25 \mathrm{~mL})$. After warming to room temperature for $20 \mathrm{~h}$, the black solution was diluted with water and extracted twice with ether. The organic phases were combined, washed with saturated aqueous sodium chloride, dried $\left(\mathrm{MgSO}_{4}\right)$, and concentrated to give an orange residue. Flash chromatography (5-100\% EtOAc-hexane gradient elution) gave $14.9 \mathrm{mg}(4.6 \%)$ of 2,3a-diphenylhexahydrocyclopenta-[b]-pyrrole (not shown) and $176 \mathrm{mg}$ (54\%) of a 6:1 mixture of 40a and 40b. Major isomer 40a: IR (neat) $3336(\mathrm{w}), 1949(\mathrm{w}), 1880$ (w), 1806 (w), 1737 (w), 1603 (m), 1494 (m), 1446 (m), 751 (s) cm ${ }^{-1}$; ${ }^{1} \mathrm{H}-\mathrm{NMR}$ (300 MHz, $\left.\mathrm{CDCl}_{3}\right) \delta .7 .3(\mathrm{bm}, 10 \mathrm{H}), 4.45(\mathrm{dd}, 1 \mathrm{H}, J=5.5,11.0 \mathrm{~Hz}), 4.15(\mathrm{dd}, 1 \mathrm{H}, J=4,8 \mathrm{~Hz}), 2.47$ (dd, $1 \mathrm{H}, J=7,12 \mathrm{~Hz}), 2.4-1.6(\mathrm{bm}, 7 \mathrm{H}) ;{ }^{13} \mathrm{C}-\mathrm{NMR}\left(75 \mathrm{MHz}, \mathrm{CDCl}_{3}\right) \delta .150 .3(\mathrm{~s}), 143.6(\mathrm{~s}), 128.4$, 127.0, 126.7, 126.0, 125.5, $69.9(\mathrm{~d}), 61.9(\mathrm{~d}), 58.7(\mathrm{~s}), 51.9(\mathrm{t}), 41.6(\mathrm{t}), 37.3(\mathrm{t}), 25.9(\mathrm{t})$. MS (EI, $\mathrm{m} / \mathrm{z}, \%) 263$ (65, M $\mathrm{M}^{+}$), 262 (23), 220 (17), 186 (6), 158 (100), 130 (40), 115 (23), 106 (46), 91 (32). Minor isomer 40b: IR $\left(\mathrm{CHCl}_{3}\right) 1949$ (w), 1884 (w), $1811(\mathrm{w}), 1600$ (w), 1496 (m), 1455 (m) $\mathrm{cm}^{-1} ;{ }^{1} \mathrm{H}-\mathrm{NMR}\left(360 \mathrm{MHz}, \mathrm{CDCl}_{3}\right) \delta 7.3(\mathrm{bm}, 10 \mathrm{H}), 4.23(\mathrm{dd}, 1 \mathrm{H}, \mathrm{J}-5.3,11.2 \mathrm{~Hz}), 4.11(\mathrm{~d}$, $1 \mathrm{H}, J=5.7 \mathrm{~Hz}), 2.47(\mathrm{dd}, 1 \mathrm{H}, \mathrm{J}-5.3,12.6 \mathrm{~Hz}), 2.1-1.6(\mathrm{bm}, 7 \mathrm{H}) ;{ }^{13} \mathrm{C}-\mathrm{NMR}\left(75 \mathrm{MHz}, \mathrm{CDCl}_{3}\right) \delta$ 128.3, 127.1, 126.7, 126.3, 125.7, 69.1, 61.8, 58.8, 50.5, 42.2, 35.3, 24.3; MS (EI, m/z, \%) 264 (12), 263 (73, $\mathrm{M}^{+}$), 262 (23), 220 (11), 158 (100), 143 (32), 130 (28), 115 (12), 106 (30). On the mixture of 40a and 40b: Anal. Calcd. for $\mathrm{C}_{19} \mathrm{H}_{21} \mathrm{~N}$ : C, 86.69; H, 8.04; N, 5.32. Found: C, 86.45; H, 8.04; N, 5.28 .

Procedure 2. Cycloreversion of imidazolidine 39. $n$-Butyllithium $(0.55 \mathrm{~mL}$ of a $1.3 \mathrm{M}$ solution in hexane, $0.71 \mathrm{mmol})$ was added in a dropwise fashion to a cold $\left(-78^{\circ} \mathrm{C}\right)$ solution of the imidazolidine 39 (203 mg, $0.477 \mathrm{mmol}$, see below for preparation) in THF (47 mL). After $10 \mathrm{~min}$, the solution was warmed to room temperature overnight. The dark solution was diluted with water and extracted with ether. The organic layer was washed with brine, dried $\left(\mathrm{MgSO}_{4}\right)$, and concentrated. Chromatography as above gave $66.5 \mathrm{mg}(53 \%)$ of a 1:11 mixture of 40a and 40b. A trace of 2,3a-diphenylhexahydrocyclopenta-[b]-pyrrole was also isolated.

\section{2,4-Diphenyl-3-hexyl-5-pentylimidazolidine (28) and 4,5-diphenyl-3-hexyl-2-pentyl-} imidazolidine (29). A round-bottomed flask was charged with $4.54 \mathrm{~g}(0.024 \mathrm{~mol}$.) of the imine 27 and $125 \mathrm{~mL}$ of dry THF and cooled to $2-3{ }^{\circ} \mathrm{C}$. This cold solution was treated with $9.0 \mathrm{~mL}$ of a 1.6 $M$ solution of LDA in cyclohexane and allowed to stir on the ice-bath. The reaction mixture slowly became orange and then gradually became a dark black. After stirring for five hours, the dark solution was quenched with water, this addition causing the reaction mixture to change to a light-yellow color. The mixture was diluted with water and extracted with ether. The organic phase was washed with brine, dried $\left(\mathrm{MgSO}_{4}\right)$, and concentrated to give $3.77 \mathrm{~g}$ (83\% crude yield) of a 4.8:1.0 mixture of $\mathbf{2 8}$ and $\mathbf{2 9}$ as a yellowish oil, as determined by ${ }^{1} \mathrm{H}-\mathrm{NMR}$. When a similar reaction was run using benzene as solvent, a 1:4.3 mixture of $\mathbf{2 8}$ and $\mathbf{2 9}$ was obtained. Data for 
28, obtained on the 4.8:1 mixture from the THF reaction: IR (film): $3342(\mathrm{vw}), 3064(\mathrm{w}), 3030$ (w), 2957 (vs), 2931 (vs), 2858 (s), $1948(\mathrm{vw}), 1882$ (vw), 1809 (vw), 1603 (w), 1490 (m), 1457 (m), $1164(\mathrm{~m}), 753$ (s), 700 (vs) cm ${ }^{-1} .{ }^{1} \mathrm{H}-\mathrm{NMR}\left(300 \mathrm{MHz}, \mathrm{CDCl}_{3}\right): \delta 7.64(\mathrm{~m}, 2 \mathrm{H}), 7.52(\mathrm{~m}$, 2H), 7.45-7.15 (m, 6H), $4.51(\mathrm{~s}, 1 \mathrm{H}), 3.40(\mathrm{~d}, 1 \mathrm{H}, J=7.2 \mathrm{~Hz}), 3.15(\mathrm{~m}, 1 \mathrm{H}), 2.41$ (dist. $\mathrm{t}, 2 \mathrm{H})$, $2.15(1 \mathrm{H}, \mathrm{N}-\mathrm{H}), 1.5-0.7(\mathrm{bm}, 22 \mathrm{H}) .{ }^{1} \mathrm{H}$ decoupling: Irradiation at $\delta 3.40$ caused the multiplet at $\delta$ 3.15 to collapse. ${ }^{13} \mathrm{C}-\mathrm{NMR}\left(75 \mathrm{MHz}, \mathrm{CDCl}_{3}\right): \delta$ 143.5, 143.1, 128.4, 128.2, 128.1, 127.7, 127.6, $127.1,82.6,75.8,66.3,52.4,34.6,32.0,31.4,27.7,27.0,26.8,22.6,22.4,14.0,13.9 . \mathrm{MS}, \mathrm{m} / \mathrm{z}$ (\%): 378(0.3, $\left.\mathrm{M}^{+}\right), 377(1.1), 301(4), 279(3), 208(0.8), 202(2), 194(4), 190(100), 174(1.4), 118(5)$, 91(9). Data for 29, obtained on the 1:4.3 mixture from the benzene reaction: ${ }^{1} \mathrm{H}-\mathrm{NMR}(300$ $\left.\mathrm{MHz}, \mathrm{CDCl}_{3}\right): \delta 7.3-7.15(\mathrm{~m}, 10 \mathrm{H}), 4.12(\mathrm{~d}, 1 \mathrm{H}, J=7.6 \mathrm{~Hz}), 3.87(\mathrm{dd}, 1 \mathrm{H}, J=3.0,7.1 \mathrm{~Hz}), 3.57$ $(\mathrm{d}, 1 \mathrm{H}, J=7.6 \mathrm{~Hz}), 2.55(\mathrm{~m}, 2 \mathrm{H}), 1.9-0.7(\mathrm{bm}, 22 \mathrm{H}) .{ }^{1} \mathrm{H}$ decoupling: Irradiation of the doublet at $\delta .12$ caused the doublet at $\delta 3.57$ to collapse to a singlet. ${ }^{13} \mathrm{C}-\mathrm{NMR}\left(75 \mathrm{MHz}, \mathrm{CDCl}_{3}\right): \delta .142 .4$, $128.3,128.2,127.8,127.1,80.6,78.3,69.4,52.5,36.5,32.5,31.6,28.1,27.8,25.1,22.8,22.6$, 14.1, 14.0. MS, $m / z(\%): 377(2, \mathrm{M}-1), 376(7), 375(3), 320(20), 299(6), 277(6), 250(13), 243(27)$, 187(50), 186(100), 180(56), 158(21), 144(19), 91(36). Anal. Calcd. for $\mathrm{C}_{26} \mathrm{H}_{38} \mathrm{~N}_{2}$ : C, 82.55; H, 10.04; N, 7.41. Found: C, 82.58; H, 10.01; N, 7.47.

5-Pentyl-2,3,4-triphenylpyrrolidine (30). A round-bottomed flask was charged with $0.223 \mathrm{~g}$ ( $0.589 \mathrm{mmol}$ ) of a 4.8:1 mixture of $\mathbf{2 8}$ and $\mathbf{2 9}$ (obtained from the above dimerization carried out in THF), $0.217 \mathrm{~g}(1.2 \mathrm{mmol})$ of trans-stilbene and $12 \mathrm{~mL}$ of dry THF. This solution was cooled to $-70{ }^{\circ} \mathrm{C}$ and then treated with $0.37 \mathrm{~mL}(0.59 \mathrm{mmol})$ of a $1.6 M$ solution of LDA in cyclohexane. The solution instantaneously became purple and was allowed to warm to room temperature. After 7 hours the still purple solution was quenched with aqueous ammonium chloride and extracted with ether. The organic layer was washed with brine, dried $\left(\mathrm{MgSO}_{4}\right)$, and concentrated to give $0.282 \mathrm{~g}(62 \%)$ of the title compound. ${ }^{1} \mathrm{H}-\mathrm{NMR}$ showed this material to be pure, and to be comprised of a mixture of three diastereomers in a ratio of 3.3:2:1 (30a: 30b: 30c). A mixture of isomers 30a and 30c could be separated from isomer 30b by column chromatography (25\% ethyl acetate/hexane, silica gel). IR (film, mixture of all three diastereomers): 3329 (vw), $3084(\mathrm{w}), 3061$ (w), 3028 (w), 2954 (m), 2870 (m), 2855 (m), 1948 (vw), 1875 (vw), 1809 (vw), 1602 (m), 1495 (m), 1465 (m), 1453 (m), 909 (m), 751 (m), 737 (s), 699 (vs) $\mathrm{cm}^{-1}$. Peaks assigned to isomer 30a: ${ }^{1} \mathrm{H}-\mathrm{NMR}\left(300 \mathrm{MHz}, \mathrm{CDCl}_{3}\right): \delta .4-7.1(\mathrm{~m}, 15 \mathrm{H})$, $4.30(\mathrm{~d}, 1 \mathrm{H}, J=9.3 \mathrm{~Hz}), 3.68(\mathrm{~m}, 1 \mathrm{H}), 3.54(\mathrm{t}, 1 \mathrm{H}, J=7.8 \mathrm{~Hz}), 3.30(\mathrm{dd}, 1 \mathrm{H}, J=7.8,9.2 \mathrm{~Hz})$, $2.14(\mathrm{bs}, 1 \mathrm{H}), 1.4-1.0(\mathrm{~m}, 8 \mathrm{H}), 0.80(\mathrm{t}, 3 \mathrm{H}, J=6.7 \mathrm{~Hz}) .{ }^{1} \mathrm{H}$ decoupling: Irradiation at $\delta .4 .3$ caused the dd at $\delta 3.30$ to collapse to a singlet. Irradiation at $\delta 3.68$ caused the triplet at $\delta 3.54$ to collapse to a doublet. Irradiation at $\delta 3.54$ caused the dd at $\delta .3 .30$ to collapsed to a doublet and affected the multiplet at $\delta$ 3.68. Irradiation at $\delta 3.30$ caused the doublet at $\delta 4.30$ to collapse to a singlet and the triplet at 3.54 to collapse to a doublet. ${ }^{13} \mathrm{C}-\mathrm{NMR}\left(75 \mathrm{MHz}, \mathrm{CDCl}_{3}\right): \delta$. 142.6 , $142.3,142.2,129.2,128.2,128.1,128.0,127.8,127.5,127.3,127.0,126.8,126.2,126.0,70.6(\mathrm{~d})$, 62.8(d), 61.8(d), 57.2(d), 33.0, 31.9, 26.8, 22.5, 13.9. Anal. Calcd. for $\mathrm{C}_{27} \mathrm{H}_{31} \mathrm{~N}$ : C, 87.81; $\mathrm{H}$, 8.39; N, 3.79. Found: C, 87.62; H, 8.68; N, 3.68. Isomer 30b: ${ }^{1} \mathrm{H}-\mathrm{NMR}\left(300 \mathrm{MHz}, \mathrm{CDCl}_{3}\right): \delta$ 7.35-6.9 (m, 15H), $4.49(\mathrm{~d}, 1 \mathrm{H}, J=9.2 \mathrm{~Hz}), 3.64(\mathrm{dt}, 1 \mathrm{H}, J=4.0,8.6 \mathrm{~Hz}), 3.36(\mathrm{dd}, 1 \mathrm{H}, J=9.3$, 
$11.2 \mathrm{~Hz}), 3.12(\mathrm{dd}, 1 \mathrm{H}, J=8.9,11.2 \mathrm{~Hz}), 2.1(\mathrm{bs}, 1 \mathrm{H}), 1.6-1.1(\mathrm{~m}, 8 \mathrm{H}), 0.84(\mathrm{~m}, 1 \mathrm{H}) .{ }^{13} \mathrm{C}$ NMR $\left(75 \mathrm{MHz}, \mathrm{CDCl}_{3}\right): \delta .144 .4,141.1,140.3,128.5,128.3,128.0,127.1,126.7,126.5,126.4,69.1$, 66.0, 64.0, 61.5, 35.9, 32.0, 26.9, 22.6, 14.0. Peaks assigned to isomer 30c: ${ }^{1} \mathrm{H}-\mathrm{NMR}(300 \mathrm{MHz}$, $\mathrm{CDCl}_{3}$, partial): $\delta 4.83(\mathrm{~d}, 1 \mathrm{H}, J=9.5 \mathrm{~Hz})$.

2-( $N$-Hexyl)-2-phenyl-l-pentyl-1, 2-ethanediamine (32) and 1,2-diphenyl-2-( $N$-hexyl)-1,2ethanediamine (33). A solution comprised of $11.0 \mathrm{~g}(0.029 \mathrm{~mol})$ of imidazolidines 28 and 29 (as a 1:2.7 mixture from the benzene dimerization reported above) in $50 \mathrm{~mL}$ of THF was cooled to $0{ }^{\circ} \mathrm{C}$, treated with $100 \mathrm{~mL}$ of $1.5 \%$ aqueous hydrochloric acid and allowed to stir for $12 \mathrm{~h}$. Acidbase work-up of this green solution and concentration of the dried organic extracts gave $4.06 \mathrm{~g}$ of the title compounds as a yellowish liquid. These two diamines could be conveniently separated by gradient column chromatography $(5 \%-10 \%-25 \%$ ethyl acetate/hexane, grade IV alumina, 35:1 loading.) Compound 32 was obtained as a 4.4:1 mixture of diastereomers. Compound 33 was obtained as a single diastereomer, later determined to be the $\left(R^{*}, R^{*}\right)$-diastereomer. Data for 32 (mixture of diastereomers): IR (film): 3376 (vw), 3309 (vw), 3064 (w), 3024 (w), 2956 (vs), 2926 (vs), 2871 (s), 2856 (vs), 1948 (vw), 1888 (vw), 1815 (vw), 1602 (m), 1465 (m), 1453 $(\mathrm{m}), 757(\mathrm{w}), 702(\mathrm{~s}) \mathrm{cm}^{-1} .{ }^{1} \mathrm{H}-\mathrm{NMR}$ for major diastereomer $\left(300 \mathrm{MHz}, \mathrm{CDCl}_{3}\right)$ : $\delta .7 .4-7.2(\mathrm{~m}$, $5 \mathrm{H}), 3.54(\mathrm{~d}, 1 \mathrm{H}, J=4.7 \mathrm{~Hz}), 2.91(\mathrm{~m}, 1 \mathrm{H}), 2.43(\mathrm{t}, 2 \mathrm{H}, J=7.1 \mathrm{~Hz}), 1.6-1.1(\mathrm{~m}, 18 \mathrm{H}), 0.9-0.8$ $(\mathrm{m}, 6 \mathrm{H})$. Partial ${ }^{1} \mathrm{H}-\mathrm{NMR}$ data for minor diastereomer: $\delta 3.26(\mathrm{~d}, 1 \mathrm{H}, J=7.6 \mathrm{~Hz}), 2.75(\mathrm{~m}, 1 \mathrm{H})$. ${ }^{13} \mathrm{C}-\mathrm{NMR}$ (major diastereomer only, $75 \mathrm{MHz}, \mathrm{CDCl}_{3}$ ) $\delta .141 .4,128.3,128.0,127.0,68.4,55.9$, $47.9,34.5,32.0,31.8,30.4,27.1,26.3,22.6,13.9$. MS, $m / z(\%): 291(0.2, \mathrm{M}+1), 219(0.4)$, 191(22), 190(100), 118(11), 106(26), 100(23), 79(6), 43(12). Data for 33: IR (film): 3382 (vw), 3316 (vw), 3062 (w), 3028 (w), 2954 (s), 2926 (vs), 2869 (m), 2855 (m), 1602 (m), 1492 (m), 1453 (s), 766 (m), 699 (vs), 607 (m) cm ${ }^{-1} .{ }^{1} \mathrm{H}-\mathrm{NMR}$ (300 MHz, $\mathrm{CDCl}_{3}$ ): $\delta$ 7.3-7.1 (m, 10H), 3.98 $(\mathrm{d}, 1 \mathrm{H}, J=7.1 \mathrm{~Hz}), 2.39(\mathrm{~m}, 2 \mathrm{H}), 1.8(\mathrm{bs}, 3 \mathrm{H}), 1.5-1.0(\mathrm{~m}, 10 \mathrm{H}), 0.84(\mathrm{t}, 8 \mathrm{H}, J=6.8 \mathrm{~Hz}) .{ }^{13} \mathrm{C}-$ NMR (75 MHz, $\left.\mathrm{CDCl}_{3}\right): \delta$ 143.9, 141.9, 128.0, 127.9, 127.9, 127.1, 126.8, 70.0, 62.0, 47.9, 31.7, 30.2, 26.9, 22.6, 13.9. MS, $m / z$ (\%): 225(0.07, M-71), 208(0.13), 191(19), 190(100), 118(9), 106(33), 100(0.13), 91(8), 79(10), 43(12).

4,5-Diphenyl-3-hexyl-2-(4-pentenyl)-imidazolidine (34). A solution of $0.089 \mathrm{~g}(0.3 \mathrm{mmol})$ of 33 in $5 \mathrm{~mL}$ dry benzene was treated with $0.0386 \mathrm{~g}(0.39 \mathrm{mmol})$ of 4-hexenal and heated to reflux through a Dean-Stark trap. After $90 \mathrm{~min}$, the solution was cooled and the solvent was removed in vacuo to give $0.11 \mathrm{~g}$ (100\% yield) of the title compound: IR (film): 3329 (vw), 3063 (m), 3029 (m), 2953 (vs), 2929 (vs), 2857 (s), 1948 (vw), 1882 (vw), 1822 (vw), 1641 (m), 1602 (m), 1494 (m), 1454 (s), 1376 (m), 1170 (m), 1028 (m), 993 (m), 911 (m), 759 (s), 700 (vs) cm ${ }^{-1} .{ }^{1} \mathrm{H}-\mathrm{NMR}$ $\left(300 \mathrm{MHz}, \mathrm{CDCl}_{3}\right): \delta .7 .3-7.1(\mathrm{~m}, 10 \mathrm{H}), 5.86(\mathrm{~m}, 1 \mathrm{H}, \mathrm{HC}=\mathrm{C}), 5.05\left(\mathrm{~m}, 2 \mathrm{H}, \mathrm{H}_{2} \mathrm{C}=\mathrm{C}\right), 4.11(\mathrm{~d}$, $1 \mathrm{H}, J=7.6 \mathrm{~Hz}), 3.89(\mathrm{dd}, 1 \mathrm{H}, J=2.9,6.7 \mathrm{~Hz}), 3.57(\mathrm{~d}, 1 \mathrm{H}, J=7.7 \mathrm{~Hz}), 2.55(\mathrm{~m}, 2 \mathrm{H}), 2.17(\mathrm{~m}$, 2H), $1.9-1.6(\mathrm{~m}, 4 \mathrm{H}), 1.3-1.0(\mathrm{~m}, 8 \mathrm{H}), 0.81(\mathrm{t}, 3 \mathrm{H}, J=6.9 \mathrm{~Hz}) .{ }^{13} \mathrm{C}-\mathrm{NMR}\left(75 \mathrm{MHz}, \mathrm{CDCl}_{3}\right): \delta$ $142.2,138.8,128.2,128.1,127.7,127.1,127.0,114.6,80.2,78.2,69.4,52.5,35.8,34.0,31.6$, 28.0, 27.2, 24.7, 22.6, 14.0. MS, $m / z$ 375(1, $\left.\mathrm{M}^{+}\right)$, 374(7), 373(13), 320(8), 319(7), 298(19), 297(100), 277(8), 243(36), 187(15), 186(26), 185(41), 184(93), 180(89), 170(25), 157(17), 
156(35), 131(26), 130(25), 117(23), 104(47), 91(62). Anal. Calcd. for $\mathrm{C}_{26} \mathrm{H}_{36} \mathrm{~N}_{2}$ : C, 83.00; $\mathrm{H}$, 9.57; N, 7.14. Found: C, 82.86; H, 9.49; N, 7.14.

(1R*, 2S*)-N-(1-Methylethyl)-1,2-diphenyl-1,2-ethanediamine (37). A $1 \mathrm{~L}$ flask was charged with $12.04 \mathrm{~g}$ of stilbenediamine (35) ${ }^{20}(0.0567 \mathrm{~mol})$ and $560 \mathrm{~mL}$ of THF which had been dried over Drierite. Dry acetone $(3.749 \mathrm{~g}, 0.0646 \mathrm{~mol})$ was added with stirring, followed by $30 \mathrm{~g}$ of $4 \AA$ molecular sieves. After $4 \mathrm{~h}$ at room temperature, the reaction was not complete by NMR, and $2 \mathrm{~mL}$ more acetone was added. After stirring overnight, the mixture was filtered through Celite and the filtrate was concentrated to give crude $(d, l$-)-stilbenediamine acetonide (36), which was used immediately. No other products were observed by GC or by NMR. ${ }^{1} \mathrm{H}-\mathrm{NMR}$ $\left(360 \mathrm{MHz}, \mathrm{CDCl}_{3}\right) \delta 7.35-7.15(\mathrm{~m}, 10 \mathrm{H}), 4.24(\mathrm{~s}, 2 \mathrm{H}), 2.13(\mathrm{br}, 2 \mathrm{H}), 1.53(\mathrm{~s}, 6 \mathrm{H})$.

The crude acetonide (36) from above was dissolved in $60 \mathrm{~mL}$ of absolute ethanol and treated with sodium borohydride ( $3.267 \mathrm{~g})$ in $50 \mathrm{~mL}$ of ethanol. After stirring overnight, water and dilute $\mathrm{NaOH}$ were added, and most of the ethanol was removed in vacuo. The concentrate was extracted ether $(3 \times 100 \mathrm{~mL}$. The combined ether layers were washed with brine and dried $\left(\mathrm{Na}_{2} \mathrm{SO}_{4}\right)$, then concentrated. The crude diamine was Kugelrohr distilled $\left(0.8 \mathrm{~mm} \mathrm{Hg}, 125{ }^{\circ} \mathrm{C}\right.$ air bath) to give $12.86 \mathrm{~g}$ of a colorless oil (89\% from stilbenediamine): IR (neat) 3382 (br), 3309 (br), 2961 (s), 1601, 1492, 1469, 1452 (s), 1379, 767, 700 (s) cm ${ }^{-1} ;{ }^{1} \mathrm{H}-\mathrm{NMR}\left(360 \mathrm{MHz}, \mathrm{CDCl}_{3}\right)$ $\delta 7.20-7.05(\mathrm{~m}, 10 \mathrm{H}), 3.95(\mathrm{~d}, J=7.2 \mathrm{~Hz}, 1 \mathrm{H}), 3.78(\mathrm{~d}, J=7.2 \mathrm{~Hz}, 2 \mathrm{H}), 2.60-2.45(\mathrm{~m}, J=6.2$ $\mathrm{Hz}, 1 \mathrm{H}), 1.8-1.6(\mathrm{br}, 1 \mathrm{H}), 0.93(\mathrm{dd}, J=6.2 \mathrm{~Hz}, 6 \mathrm{H}) ;{ }^{13} \mathrm{C}-\mathrm{NMR}\left(90 \mathrm{MHz}, \mathrm{CDCl}_{3}\right) \delta .143 .6$, 142.2, 127.9, 127.7, 127.6, 127.1, 126.8, 126.7, 67.0, 61.9, 45.8, 24.4, 21.9; MS (CI, isobutane, m/z, \%) 255 (100), 148 (59), 106 (50), 256 (20), 238 (16), 149 (10), 196 (6), 104 (6). HRMS calc. $255.1861(\mathrm{M}+1)$, found 255.1862 .

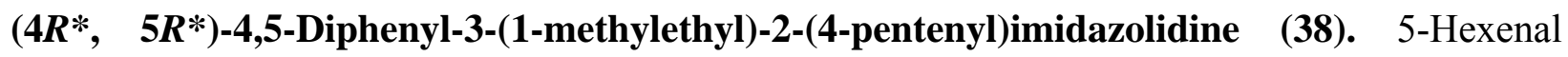
$(98 \mathrm{mg}, 1.00 \mathrm{mmol})$ and the diamine $37(254 \mathrm{mg}, 1.00 \mathrm{mmol})$ in ether $(14 \mathrm{~mL})$ were stirred overnight in the presence of $4 \AA$ molecular sieves. The mixture was filtered through Celite and concentrated to give $295 \mathrm{mg}(88 \%)$ of a pale-yellow oil that was found to be pure by ${ }^{1} \mathrm{H}-\mathrm{NMR}$; ${ }^{1} \mathrm{H}-\mathrm{NMR}\left(360 \mathrm{MHz}, \mathrm{CDCl}_{3}\right)$ d. 7.4-7.1 (m, 10H), 5.95-5.75 (m, 1H), 5.11-4.95 (m, 2H), 4.18$4.12(\mathrm{dd}, J=3.5,7.4 \mathrm{~Hz}, 1 \mathrm{H}), 4.07$ (d, $J=7.6 \mathrm{~Hz}, 1 \mathrm{H}), 3.90(\mathrm{~d}, J=7.6 \mathrm{~Hz}, 1 \mathrm{H}), 3.05-2.90(\mathrm{~m}$, $1 \mathrm{H}), 2.3-2.1(\mathrm{~m}, 2 \mathrm{H}), 2.0(\mathrm{br}, 1 \mathrm{H}), 1.9-1.3(\mathrm{~m}, 4 \mathrm{H}), 1.0-0.9(\mathrm{dd}, J=6.5 \mathrm{~Hz}, 6 \mathrm{H}) ;{ }^{13} \mathrm{C}-\mathrm{NMR}(90$ $\left.\mathrm{MHz}, \mathrm{CDCl}_{3}\right) \delta .143 .7,141.0,138.9,128.2,128.0,127.4,127.2,126.8,114.5,75.9,73.0,69.6$, 49.9, 37.9, 33.9, 25.4, 20.4, 19.6; IR (neat) 3028, 2963, 2929, 1494, 1453, 1384, 1365, 1180, 911, 759, 700. MS (EI, m/z, \%) 335(4), 266 (20), 265 (95), 149 (11), 148 (100), 106 (26), 91 (12), 81 (13); HRMS: calcd. 335.2487; found 335.2502.

(4R*, 5R*)-4,5-Diphenyl-3-(1-methylethyl)-2-(4-phenyl-4-pentenyl)imidazolidine (39). 5Phenyl-5-hexenal $(190 \mathrm{mg}, 1.09 \mathrm{mmol})$ and the diamine 37 (277 $\mathrm{mg}, 1.09 \mathrm{mmol})$ in ether $(14 \mathrm{~mL})$ were stirred overnight in the presence of $4 \AA$ molecular sieves. The mixture was filtered through Celite and concentrated to give $378 \mathrm{mg}(86 \%)$ of a pale-yellow oil that was found to be pure by ${ }^{1} \mathrm{H}-\mathrm{NMR}$; IR (neat) 3030, 2964, 2931, 2864, 1656, 1629, 1603, 1497, 1450, 1178, 1025 , 899, 779, 759, $700 \mathrm{~cm}^{-1}$; ${ }^{1} \mathrm{H}-\mathrm{NMR}\left(360 \mathrm{MHz}, \mathrm{CDCl}_{3}\right) \delta .5-6.9(\mathrm{~m}, 15 \mathrm{H}), 5.3(\mathrm{~s}, 1 \mathrm{H}), 5.13(\mathrm{~s}$, $1 \mathrm{H}), 4.15-4.10(\mathrm{~m}, 1 \mathrm{H}), 4.05(\mathrm{~d}, J=7.6 \mathrm{~Hz}, 1 \mathrm{H}), 3.9(\mathrm{~d}, J=7.6 \mathrm{~Hz}, 1 \mathrm{H}), 3.05-2.85(\mathrm{~m}, 1 \mathrm{H})$, 
2.70-2.55 (m, 2H), 2.0 (br, 1H), 1.9-1.6 (m, 4H), 1.1-0.8 (m, 6H); MS (EI, m/z, \%) $411(\mathrm{M}+1$, 1), $410\left(\mathrm{M}^{+}, 2\right), 266$ (28), 265 (100), 148 (54), 106 (15), 91 (17); HRMS: calcd. 410.2722, found 410.2706 .

\section{Acknowledgments}

We thank the National Institutes of Health for funding this research.

\section{References}

1. Semi-stabilized 2-azaallyl anions are those bearing aryl groups. Non-stabilized versions bear only alkyl or hydrogen substituents, while the presence of groups such as esters, nitriles, and phosphonates denote stabilized 2-azaallyl anions.

2. For a review of the early work in this area, see: Kauffmann, T. Angew. Chem., Int. Ed. 1974, 13, 627.

3. Pearson, W. H.; Walters, M. A.; Oswell, K. D. J. Am. Chem. Soc. 1986, 108, 2769.

4. (a) Pearson, W. H.; Szura, D. P.; Harter, W. G. Tetrahedron Lett. 1988, 29, 761. (b) Pearson, W. H.; Szura, D. P.; Postich, M. J. J. Am. Chem. Soc. 1992, 114, 1329. (c) Pearson, W. H.; Postich, M. J. J. Org. Chem. 1992, 57, 6354.

5. Pearson, W. H. Pure Appl. Chem. 2002, 74, in press.

6. An initial account of a portion of this work has appeared in an electronic proceeding: Pearson, W. H.; Walters, M. A.; Harter, W. G., Electron. Conf. Heterocycl. Chem. Royal Society of Chemistry, Cambridge, UK: 1996; p 060.

7. Kauffmann, T.; Habersaat, K.; Köppelmann, E. Angew. Chem., Int. Ed. 1972, 11, 291.

8. Kauffmann, T.; Habersaat, K.; Köppelman, E. Chem. Ber. 1977, 110, 638.

9. Bastien, G.; Crozet, M. P.; Flesia, E.; Surzur, J.-M. Bull. Soc. Chim. Fr. 1979, 606.

10. Tsujihara, L.; Furukawa, N.; Oae, K.; Oae, S. Bull. Chem. Soc. Jpn. 1969, 42, 2641.

11. Tamura, Y.; Bayomi, S. M.; Sumoto, K.; Ikeda, M. Synthesis 1977, 693.

12. Ittah, Y.; Sasson, Y.; Shahak, I.; Tsaroom, S.; Blum, J. J. Org. Chem. 1979, 43, 4271.

13. (a) Vo-Quang, L.; Vo-Quang, Y. J. Heterocyclic Chem. 1982, 19, 145. (b) Vo-Quang, L.; Vo-Quang, Y.; Povet, M. J.; Simonnin, M. P. Tetrahedron 1981, 37, 4343. (c) Vo-Quang, L.; Gaessler, H.; Vo-Quang, Y. Angew. Chem., Int. Ed. 1981, 20, 880. (d) Gracheva, R. A.; Potapov, V. M.; Sivov, N. A.; Sivova, L. I. J. Org. Chem. USSR 1981, 17, 1963.

14. Prepared from 5-hexen-1-ol by the sequence (a) Swern oxidation, (b) $\mathrm{EtP}(+) \mathrm{Ph}_{3} \mathrm{Br}(-), \mathrm{KOt}-$ $\mathrm{Bu}$, (c) $m$-CPBA, (d) $\mathrm{NaN}_{3}$, (e) $\mathrm{PPh}_{3}$.

15. Vo-Quang, L.; Vo-Quang, Y. J. Heterocyclic Chem. 1982, 19, 145.

16. Gracheva, R. A.; Potapov, V. M.; Sivov, N. A.; Sivova, L. I. J. Org. Chem. USSR 1981, 17, 1963. 
17. Kauffmann, T.; Busch, A.; Habersaat, K.; Scheerer, B. Tetrahedron Lett. 1973, 4047.

18. Bianchi, G.; De Micheli, C.; Gandolfi, R. Angew. Chem., Int. Ed. 1979, 18, 721.

19. Amornraksa, K.; Grigg, R. Tetrahedron Lett. 1980, 21, 2197.

20. Corey, E. J.; Imwinkelried, R.; Pikul, S.; Xiang, Y. B. J. Am. Chem. Soc. 1989, 111, 5493. 